\title{
Erloju zirkadianoak: zer diren, nola funtzionatzen duten eta zergatik diren garrantzitsuak
}

\author{
Circadian clocks: What are, How do they work \\ and Why are important
}

Beñat Zaldibar Aranburu*

LABURPENA: Lurrean dauden organismoek denboraren kontrola mantentzeko sistema endogenoak garatu dituzte, hainbat prozesu fisiologiko zein portaerazkoak sinkronizatzen dituztenak. Sistema hauei erritmo edo erloju zirkadianoak deritze, eta haien mekanismo molekularra deskribatzeak eta ulertzeak berebiziko garrantzia izan du biologiaren eta medikuntzaren munduan azkeneko hamarkadetan. Erloju zirkadianoek nola funtzionatzen duten eta haietan asaldurak gertatzen direnean nolako arazo eta gaixotasunak gertatzen diren azaltzea gero eta garrantzi handiagoa hartzen ari da. Izan ere, gaur egun dauden hainbat arazo (gizentasuna, gaixotasun kardiobaskularrak, minbizia...) modu zuzen edo ez-zuzen batean erlazionaturik daude erloju zirkadianoekin.

HITZ GAKOAK: Nukleo suprakiasmatikoa, osziladore molekularra, erloju-geneak, metabolismoa.

ABSTRACT: Organisms inhabiting the Earth have developed endogenous systems in order to maintain the control of time, which are able to synchronize several processes including physiological and behavioral processes. The mentioned systems are known as circadian rhythms or clocks and the description and understanding of the molecular basic mechanisms lying inside these systems has widely increased in the last decades in biological and medical studies. The understanding of the functioning of circadian clocks and the diseases and problems (obesity, cardiovascular diseases, cancer...) derived from an altered circadian system is of increasing interest. In fact, many of the aforementioned disorders are directly or indirectly related with circadian clocks.

KEYWORDS: Suprachiasmatic nucleus, molecular oscillator, clock genes, metabolism.

\footnotetext{
* Harremanetan jartzeko / Corresponding author: Beñat Zaldibar Aranburu, Dept. Zoology and Animal Cell Biology, Faculty of Science and Technology, UPV/EHU, Barrio Sarriena s/n, E-48940. Leioa. Bizkaia. Euskal Herria. - benat.zaldibar@ehu.eus https://orcid.org/0000-0002-5528-451X.

Nola aipatu / How to cite: Zaldibar Aranburu, Beñat (2019). «Erloju zirkadianoak: zer diren, nola funtzionatzen duten eta zergatik diren garrantzitsuak»; Ekaia, 35, 2019, 225-238. (https://doi.org/10.1387/ekaia.20339).

Jasoa: 6 azaroa, 2018; Onartua: 11 abendua, 2018.

ISSN 0214-9001 - eISSN 2444-3255 / (c) 2019 UPV/EHU
}

(c) (i) () Obra hau Creative Commons Atribución 4.0 Internacional-en lizentziapean dago 


\section{SARRERA}

Lehen hezkuntzako edozein ikasleri erakusten zaionez, Lurrak Eguzkiaren inguruan bira egiten du, translazio-higidura eginez, eta bere ardatzaren inguruan ere biratzen da. errotaziozko mugimenduak burutuz. $\mathrm{Mu}-$ gimendu hauek duela milioika eta milioika urte gertatzen dira, eta lurrean dagoen bizitza ez da mugimendu hauek sortzen dituzten efektuekiko independentea. Errotazio-mugimenduak direla eta, argitasun/iluntasun ziklo sendoa sortzen da planetan, latitudearen edo sasoiaren arabera aldatu egiten dena. Argiztapen ziklo natural horren aurrean gure planetan bizi diren organismo guztiek, izaki unizelularretatik gizakietara, denboraren kontrola mantentzeko sistema endogenoak garatuz eboluzionatu dute. Sistema hauek prozesu fisiologikoak eta portaerazko prozesuak sinkronizatzen dituzte. Esan dezakegu, beraz, erritmo edo erloju zirkadianoak (grekeraz; circa; inguru eta dies; eguna) eguneko denbora neurtzen duen barne-kadentzia edo -erritmoaren mekanismoaren kanpo-adierazpena direla. Elikadura-portaerak, lo/esna zikloak, hormona-mailak eta baita gorputzaren tenperatura ere erloju zirkadianoaren eraginpean dauden prozesu fisiologikoak dira.

Erritmo eta erloju hauen menpe egonik eguneroko hainbat eta hainbat prozesu eta funtzio, ez da harritzekoa 2017ko Nobel saria erritmo honen atzean dagoen mekanismo molekularra deskubritu eta deskribatu zuten ikertzaileei (Jeffrey C. Hall, Michael Rosbach eta Michael W. Young) eman izana.

Aspalditik ezagutzen dugu argitasun/iluntasun zikloek bizidunen portaeran eragina dutela. Daukagun informazioaren arabera, landareen portaera eguneko momentuaren arabera aldatzen zela deskribatu zuten grekoek duela ia 25 mende. Hala ere, gai honen inguruko lehendabiziko ikerketa sakonak Jean-Jacques d'Ortous de Mairan frantziar astronomo eta geofisikariak burutu zituen XVIII. mendean, «Observation botanique» izenburuko lanean [1]. Han, Mimosa pudica minberan hostoak argitasuna zegoenean zabaldu egiten zirela eta ilunabarrean ixten zirela jakinik, landareok etengabeko iluntasunean mantendu zituen. Ikertzaile frantziarrak, nahiz eta etengabeko iluntasunean mantendu, landare hauen portaera ez zela aldatzen behatu zuen, hau da, hostoak modu zikliko batean irekitzen eta ixten ziren. Beraz, landare hauek nolabaiteko barne-erloju bat zutela ondorioztatu zuen, eguzkiaren argitasunarekiko independentea zena.

Hala ere, mekanismo erritmiko honen jatorriaren azpian dauden mekanismo molekularrak azaltzeko lehendabiziko saioek xx. mendearen bigarren erdira arte itxaron behar izan zuten [2,3]. Azken lan honetan, fruta euliaren (Drosophila melanogaster) X kromosoman eta 3A6 eta 3C2 banden artean kokatutako gene baten adierazpen ezak fisiologia eta portaera desberdina eta arritmikoa eragiten zuela ikusi zuten. Autoreek gene horri 
period izena jarri zioten, nolabaiteko periodikotasuna ematen ziolako euliaren eklosioari eta lokomozio-jarduerei. Konopka eta Benzer-en ikerketek erritmo zirkadianoen genetika molekularraren oinarriak ezarri zituzten, eta sekulako eragina izan zuten hurrengo bi hamarkadetan. 90eko hamarkadaren hasieran, euliaren burmuinean PER proteina (period genearen produktua da) modu erritmikoan adierazten zela behatu zuten Nobel saridun izan diren Jeffrey C. Hall eta Michael Rosbach-ek: gauaren hasieran maila altuenak erakutsiz eta bere RNA mezulariaren kontzentrazio-mailarik altuena proteinarena baino 6 ordu lehenago gertatuz [4]. Emaitza hauetan oinarrituta, autoreek, beranduago ikusiko dugun trankskripzio-itzulpenen atzeraelikaduraren begizta proposatu zuten. Hurrengo urteetan, period geneaz gain, erloju endogeno horren parte ziren beste hainbat gene eta proteina identifikatu eta haien erregulazio-mekanismoak deskribatu dira. Aipatu bezala, erritmo zirkadiano horiek berebiziko garrantzia duten hainbat prozesuren gain eragiten dute (hormonen erritmoak, elikadura edota ernalketa-portaerak). Beraz, ikus dezagun zehaztasun gehiagorekin erritmo horrek zelula- eta molekula-mailan duen portaera.

Erloju zirkadianoa hiru zatitan antolaturik dagoela esan genezake. Alde batetik, sarrera-bidezidorra, non organismoak ingurumeneko kinadak jasotzeko hartzaileak dituen eta kinada hauek osziladore zentralera garraiatzen duen; bestetik, osziladore zentrala, non denbora zirkadianoa mantendu eta erritmoa ezartzen den; eta azkenik, irteera-bidezidorra, non erritmoa hainbat prozesu fisiologiko eta metabolikoren kontrol gisa adierazten den.

\section{KINADAREN SARRERA}

Erritmo zirkadianoek behar bezala funtzionatzeko, nolabaiteko erlojuak behar dituzte eta hauek doitzeko dagoen kinadarik esanguratsuena egunero gertatzen den argitasun/iluntasun zikloa da. Ugaztunen kasuan, jakin badakigu argia begietaraino heltzen dela, eta begietan hainbat interakzio gertatzen direla; besteak beste, begian dagoen erretina eta argi-izpietan dauden fotoien artekoa. Begia, nagusiki hutsik dagoen organoa da, biribil antzekoa, baina haren pareta osatzen duten 3 geruza bereizten ditugu. Begiaren paretan, eta kanpo aldera begira, zuntz-tunika dago. Zuntz-tunikaren aurrealdean kornea dago (gardena da), eta atzealdean esklera deitzen den geruza bat dago. Erdiko geruzan, tunika baskularra edo uvea geruza dago; erdiko geruza honen aurrealdean irisa eta gorputz ziliatua kokatzen dira, eta atzealdean koroidea dago; eta azkenik, barneko geruzan erretina kokatzen da. Erretinak begiaren atzeko alde guztia betetzen du (nerbio optikoa alde batera utzita) ora serrata arte. Erretinaren lodiera aldakorra da. Horrela, macula-ren zonaldean $400 \mu \mathrm{m}$-tako lodiera dauka eta fovea-n $150 \mu \mathrm{m}$-tako lodiera dauka. Erretinaren nerbio-zuntzak begitik (begiaren atzeko aldetik) 
luzatu eta ateratzen dira, nerbio optikoa osatuz. Erretinan hainbat zelula mota aurkitu ditzakegu; besteak beste, nerbio-zelulak, glia-zelulak eta zelula fotohartzaileak [5]. Guk azken hauek izango ditugu hizpide.

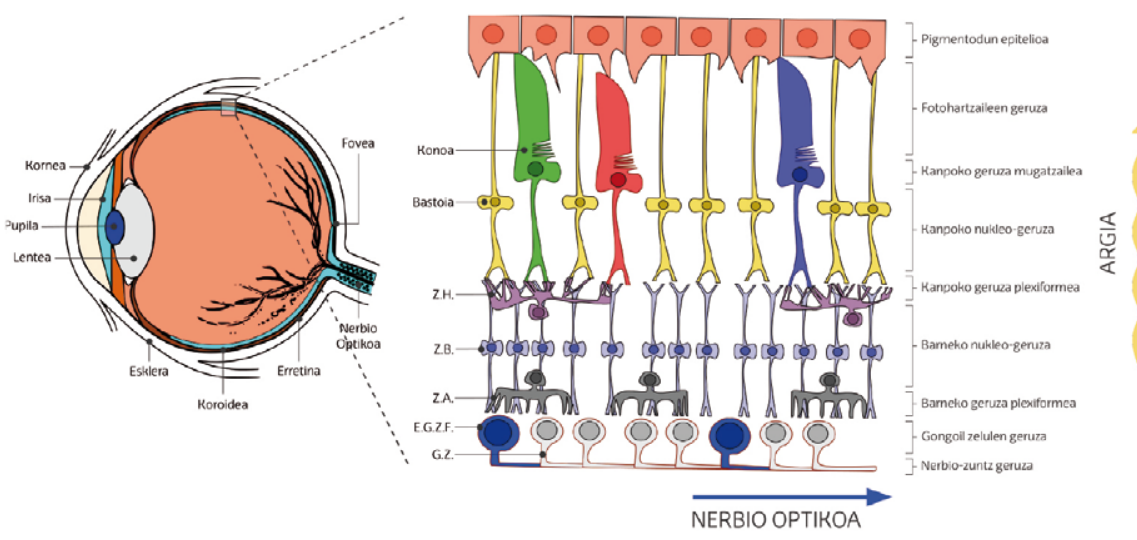

1. irudia. Begiaren eskema orokorra (ezkerrean), egitura nagusiekin, eta erretinaren epitelioaren antolaketa zelula-mailan. (Z.H. Zelula horizontalak; Z.B. Zelula Bipolarrak; Z.A. Zelula Amakrinoak; E.G.Z.F. Erretinako Gongoil Zelula Fotosentikorrak; G.Z. Gongoil-zelulak).

Zelula fotohartzaileen artean, zelula mota nagusiak konoak eta bastoiak ditugu. Konoek hobeto funtzionatzen dute argitasun handiarekin, eta bastoiek argitasun gutxirekin. Zelula hauek oso espezializazio-maila altua erakusten dute, eta ikuspuntu anatomiko batetik begiratuta, bi taldetan banatzen dira: kanpoko eta barneko segmentuak, hain zuzen. Kanpoko segmentuan disko itxurako zenbait egitura erakusten dituzte, eta han opsina proteinak (rodopsinak eta konopsinak, nagusiki) mintz-egituretan kokatzen dira. Barneko segmentuan, zelulen nukleoa eta bestelako organuluak kokatzen dira. Zelula hauei esker, seinale bisualak burmuinera transmititzen dira erretinako gongoil-zelulen (Retinal Ganglion Cells; RGC) bitartez. Zelula hauen axoiek nerbio optikoa osatzen dute, eta burmuinera heltzean objektuen jarraipena eta formen interpretazioa burutzen da. RGC sistemako zelula batzuek (RGC zelulen \%1 inguru), ordea, inguruneko argitasun-maila dekodifikatzen dute, baina formen inguruko informaziorik eman gabe. Zelula hauetan agertzen den pigmentua melanopsina da. Aipatu beharra dago melanopsina pigmentua kono eta bastoietan agertzen diren pigmentuekiko desberdin samarra dela, baina hainbat organismotan (olagarroak, igelak...) deskribatu den melanopsinaren antzekoa da. Melanopsinatan aberatsak diren RGC zelula berezi hauen seinalea burmuinaren eskualde berezi batera heltzen da, hipotalamoko nukleo suprakiasmatikora, hain zuzen (SupraChiasmatic Nucleus; SCN) [6] (1. irudia) eta SCN hau da, hain zuzen, 
organismoan daukagun erloju zirkadiano nagusia. Prozesu honetan, glutamatoa eta PACAP (Pituitary adenylate cyclase-activating polypeptide) dira neurotrasmisore nagusiak. SCN-ren neuronetan (itu-zelulak), glutamatoaren menpekoa den $\mathrm{Ca}^{++}$sarrera gertatzen da. Kaltzioaren sarrerak, proteina kinasa bidezidorrak (CREB (Ca++/cAMP-response element binding protein) aktibatzen ditu. CREB ituen artean, perl eta per2 geneak (mekanismo erritmikoak martxan jartzen dituzten eta mantentzen dituzten gene nagusiak) daude.

\section{OSZILADOREAREN ERLOJU MOLEKULAR ZIRKADIANOA}

Erloju zirkadianoaren oinarrizko egitura molekula-mailan atzeraelikadura negatiboa (negative feedback) duen transkripzio eta itzulpenean oinarritutako zirkuitu bat da, eta han erloju-geneak (clock genes) modu koordinatuan erregulatzen dira.

Ugaztunetan bi zirkuitu bereizten dira; alde batetik, zirkuito zentrala edo guneko zirkuitoa, non transkripzioaren aktibatzaile clock eta bmall geneak agertzen diren eta transkripzioaren errepresore period 1-3 (per1-3), cryprochrome (cry) 1 eta 2 geneak agertzen diren. Guneko zirkuituari lotuta, eta oszilazio zirkadianoa indartuz, bigarren azpizirkuitu (sekundarioa) bat agertzen da; han REV-ERB eta ROR (azido retinoikoaren hartzailearekin erlazionatutako hartzaile-zurtza) proteinek berebiziko garrantzia dute. Erloju-proteina hauen adierazpen erritmikoan kontrol kuantitatiboa (proteina kopurua) zein kualitatiboa (kokapena eta jarduera) garrantzitsuak dira. Arratoien kasuan, goizean CLOCK eta BMAL1 proteinek (transkripzio-faktoreak dira) per familiako eta cry familiako geneen adierazpena bultzatzen dute. PER eta CRY proteinak arratsaldean eta gauaren hasieran zitoplasman metatzen dira. Gauean zehar, PER eta CRY elkarrekin lotzen dira, eta baita Kaseina kinasa $1 \delta$ eta $\varepsilon$-rekin ere, nukleora translokatuz. Han, CLOCK eta BMAL1-era lotzen dira beren transkripzioa (eta bide batez, per eta cry-ren transkripzioa ere) erreprimituz. Hori dela eta, PER eta CRY-ren kontzentrazioak txikitu egiten dira. PER eta CRY-ren batez besteko bizitza laburra da: izan ere, E3 Ligasa konplexuek proteina hauek ubikuitinizatu eta proteosoman andeatzen dira. Atzeraelikadura hau konplexu erreprimitzailearen ordezkapena dela-eta arintzen denean, CLOCK eta BMAL1 ziklo berri bat jarri dezakete martxan. Guneko zirkuituaz gain, CLOCK-BMAL1 konplexuek REV-ERB $\alpha$ eta REV-ERB $\beta$ hartzaile nuklearrak aktibatzen dituzte, eta hauek RORE elementuekin (ROR $\alpha$, ROR $\beta$ eta ROR $\gamma$-rekin) konpetitzen dute. REV-ERB eta ROR bmall-en adierazpena erregulatzen dute baita modu zikliko batean [8]. Sistema honek martxan jartzen ditu modu zikliko batean irteera-geneak (erlojuaren menpe dauden geneak eta organismoaren bestelako funtzio batzuk kontrolatzen dituztenak; ikusi aurrerago) (2. irudia). 


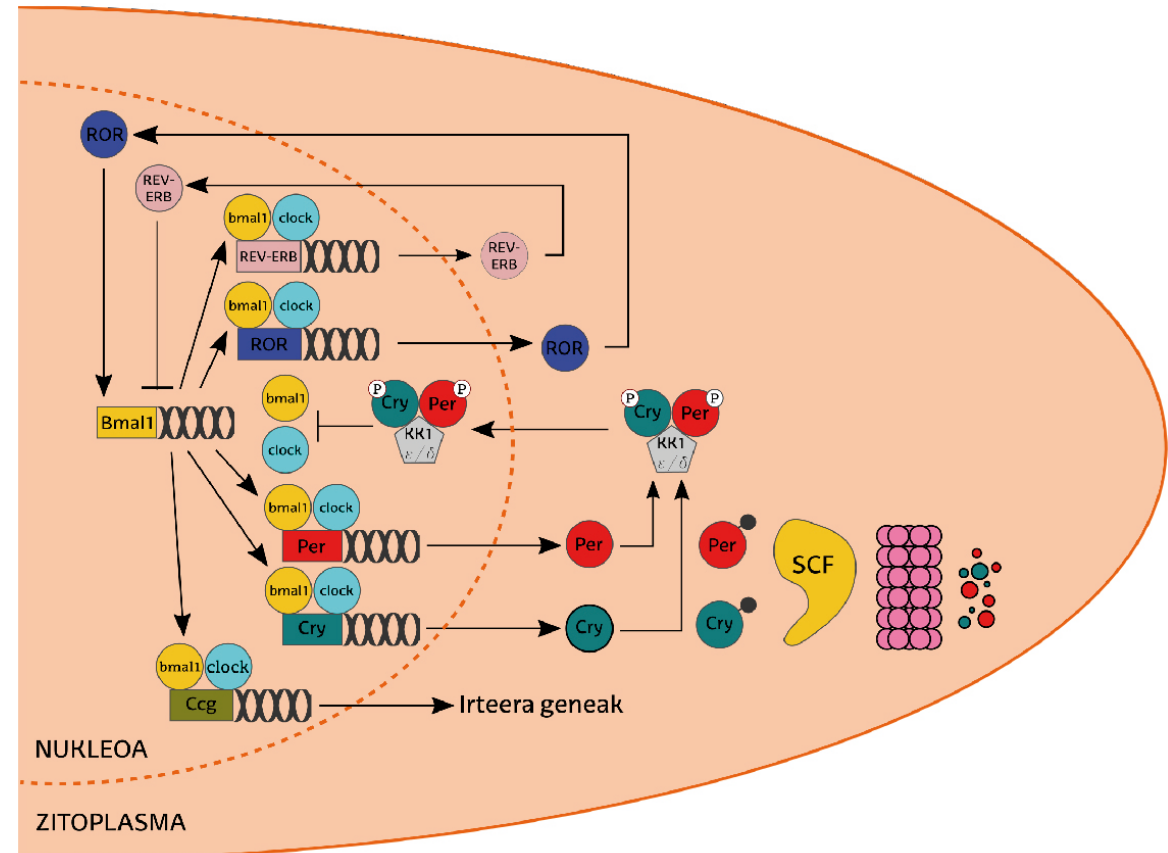

2. irudia. Ugaztunetako osziladore zirkadianoan parte hartzen duten geneen eskema orokorra. Borobil beltzek ubikuitinizazioak adierazten dituzte.

Aipatutako mekanismoaz gain, itzulpen ondorengo aldakuntzak ere badituzte zikloan parte hartzen duten proteinek (fosoforilazioak, ubikuitinazioak, azetilazioak...) [9]. PER eta CRY elkarrekin lotzen dira, eta baita Kaseina kinasa $1 \delta$ eta $\varepsilon$-rekin ere. PER-en fosforilazioa amino terminalean gertatzen bada, E3 ligasak ( $\beta$-TrCP1 edo $\beta$-TrCP2, besteak beste) erakartzen dituzte, eta ondoren SCF (Skp-Cullin-F-box) konplexuaren bitartez poliubikuitinizatzen da, eta azkenean, proteosoman degradatzen da. Fosforilazioa, amino terminalean gertatu beharrean Ser662-an eta beherago dauden 4 serinetan gertatzen bada, PER-en gaineko errepresio-mailak txikitu egiten dira, PER-en estabilizazioa baimenduz [10].

CRY proteinari dagokionez, itzulpen ondorengo erregulazioa ere izango du. Horretarako, FBXL3-k (F-box-type E3 ligasa) eta haren homologoa den FBXL21-ek elkarrekin konpetitzen dute, ubikuitinak CRY-ren hondar desberdinetara lotuz, eta modu horretan CRY-ren andeakuntza proteosoman bultzatuz edo haren estabilitatea bultzatuz. CRY-ren desegonkortzea bultzatzen duen beste faktore bat PER-ekiko dimerizazioa da. Dirudienez, PER-ek, CRY-FBXL3 konplexuarekin elkarrekintzak dituenean, FBXL3 kanporatzen du konplexutik CRY-ren andeakuntza ekidinez [11]. 


\section{ERRITMO ZIRKADIANOA ETA METABOLISMOA}

Erritmo zirkadianoen garrantziaz jabetzeko, soilik aipatu behar da ugaztunen kasuan transkriptomaren \%10ek maila altuago edo baxuago batean erritmo zirkadianoren bat jarraitzen duela, eta horietako asko elikagaien metabolismoarekin loturik daudela [12]. Ez da harritzekoa, beraz, gauez lanean diharduten pertsonek, eta hortaz, beren erritmo zirkadianoa nolabait asaldatuta duten pertsonek, ez soilik loezin edo umore-aldaketak izatea, baizik eta desgaitasun kognitiboarekin, disfuntzio metabolikoekin eta baita minbizi arrisku handiagoekin ere erlazionatu izana [13].

Nola eragiten dute, beraz, erritmo zirkadianoan parte hartzen duten geneek gure metabolismoan? Erantzuna konplexua da, eta puzzle honetako hainbat pieza falta zaizkigun arren, badaukagu zenbait bide eta eraginen inguruko informazioa.

Aipatu bezala, SCN da gure erloju zirkadiano nagusia, baina organismoko hainbat eta hainbat ehun eta organok ere SCN sistemarekin sinkronizaturik daude [14]. SCN-an sortzen den jarduera zirkadianoa gorputzaren beste organo eta ehunetara heltzeko bi mekanismo nagusi daude; (i) neurona-sarea, non zuzenean zerebroko beste zonaldeekin interakzioak burutuz seinalea (eta erritmoa) transmititzen den; eta (ii), hainbat seinale hormonalen bitartez, glukokortikoideak beste batzuen artean, itu organoetara helduz $[15,16]$. Era berean, seinaleztapen parakrinoaren bitartez sinkronizatzen dira eta mantentzen dira erritmo zirkadianoak hainbat organotan: gibela, bihotza, giltzurrunak edo birikak [17].

Beraz, burmuinean dagoen erloju zentralaz gain organismoan zehar baditugu hainbat erloju periferiko, eta haiek ere portaera erritmikoa erakusten dute (3. irudia), haien jarduera uhin bat bezala (maximo eta minimoak modu ziklikoan emanez) gertatzen delarik.

Erritmo honek organismoan duen garrantzia erakusteko, adibide argi bat metabolismo lipidikoarekin eta obesitatearekin erlazionatuta dagoena da. Laburki, dietarekin batera sartzen diren lipidoen eraldaketa metabolikoa hestearen lumenean burutzen da, han gatz biliarrek emultsionatzen dituzten mizelak sortuz. Areako fosfolipasen jarduera dela-eta, gantzazido askeak sortzen dira, eta haiek enterozitoetan (heste-epitelioan dauden zelulak) barneratzen dira difusioz zein proteina garraiatzaileen bitartez [18]. Gantz-azido askeak erretikulu endoplasmatiko leunean metatu eta transformatzen dira, eta ondoren kilomikronetan (triglizerido, fosfolipido, kolesterol eta proteinez osaturiko partikulak) metatzen dira. Kilomikron hauen azalean, besteak beste, Apolipoproteinen (APO) familiako molekulak ageri dira. 


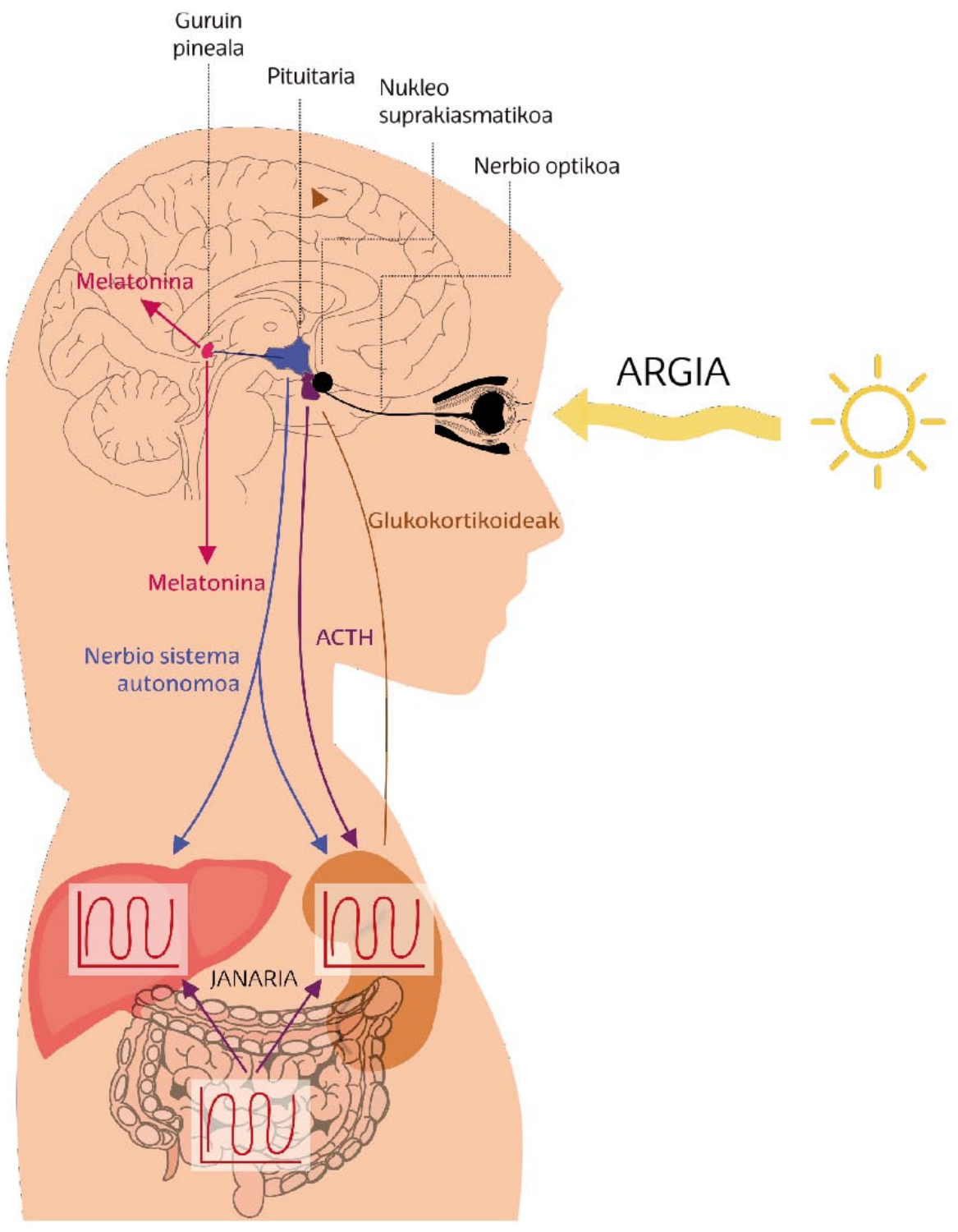

3. irudia. Erloju zirkadiano zentral eta periferikoen arteko interakzioen arteko irudi eskematikoa. Organoetan azaltzen diren uhinak, organo horietan eraenketa zirkadianoa (jarduera maximo eta minimo ziklikoak) pairatzen dutela adierazten dute. ACTH (Hormona adrenokortikotropikoa). [15]-etik moldatua. 

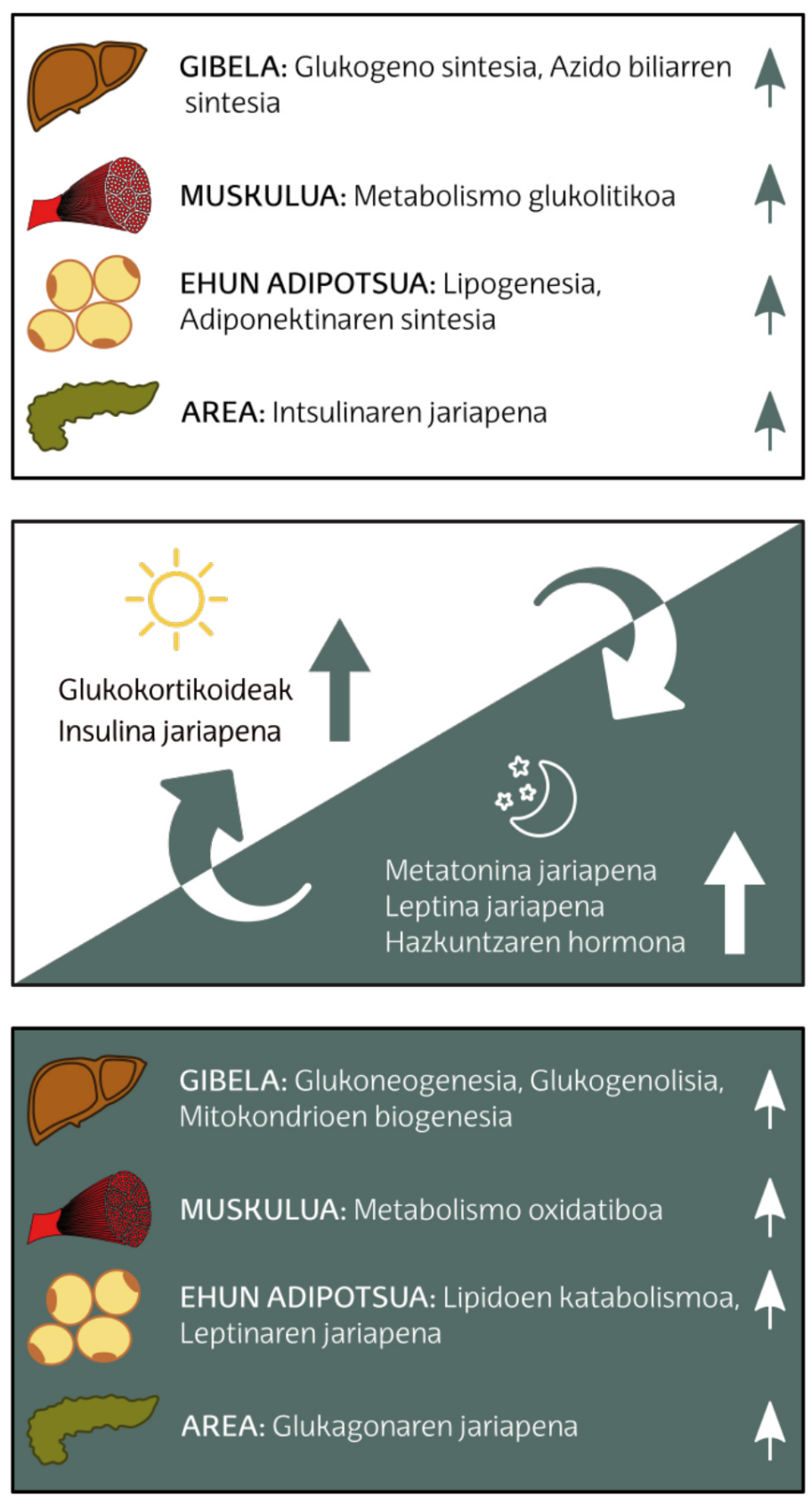

4. irudia. Gizakietan gertatzen den erritmo zirkadianoaren, metabolismoaren eta hormonen homeostasiaren asoziazio estuaren irudi eskematikoa. [15]-etik moldatua. 
Enterozitoetan, erritmo zirkadianoko geneak ere modu zikliko batean adierazten dira, baina janariaren sarrerarekin sinkronizatuta dago. Erritmo zirkadianoarekin erlazionatutako zenbait genetan mutazioak erakutsi dituzten saguek (clock genea nagusiki), ordea, gehiegizko triglizeridoen xurgapena erakusten dute hesteko zeluletan. CLOCK-ek mtp (ingelesezko; microsomal triglyceride transfer protein) genearen adierazpena erreprimitzen du, eta, beraz, $m t p$-ren adierazpen ziklikoa galtzen da. MTP guztiz beharrezkoa da APO proteinak funtzionalak izateko, eta, beraz, kilomikron funtzionalak lortzeko [15]. Lipidoen garraioaz gain, dirudienez, clock geneak ere eragina dauka lipidoen sintesian ere. Beste alde batetik, BMAL1-ek ere adipozitoen desberdintzapenean parte hartzen du lipogenesia bultzatuz [18]. Izatez bmall -/- arratoiek gantz-azido kontzentrazio altuak erakutsi zituzten odolean, eta gantz ektopikoa ere erakutsi zuten gibel zein muskulu ildaskatuan [13, 14].

Hala ere, aipatu beharra dago erloju zirkadianoaren eta metabolismoaren arteko interakzioa bi norantzakoa dela. Ikusi dugun moduan, erritmo zirkadianoko gene eta proteinetan sortzen diren alterazioak loditzea eta metabolismo lipidikoan eragina daukate, baina gantzetan aberatsak diren dietak dituzten arratoiek ere ziklo zirkadiano luzeagoak (eta, beraz, asaldatuak) erakusten dituzte [19].

Eguneroko argitasun-jarduera/iluntasun-loa baldintzetatik urruntzen garenean, aldaketa metabolikoak sortzen dira; izan ere, etengabe argipean mantendutako saguek gehiegizko pisua eta glukosa metabolizatzeko ahalmen murritzagoa erakutsi zuten [20]. Gizakietan ere sinkronia esperimentalki apurtzen denean (jet-lag baldintzak edo turnoka lan egitea imitatuz), besteak beste glukosaren tolerantzia-maila txikiagoak eta hipoleptinemia (leptina, gorputzaren balantze energetikoa erregulatzen duen hormona da) asaldurak behatu dira [21].

Metabolismoan duen eraginaz gain, erloju zirkadianoak hazkuntza eta biziraupen zelularrean ere parte hartzen du, eta DNA kaltetuaren aurreko erantzunak eragin zuzena du zelulen zikloan eta zahartzapenean. Hori dela eta, minbizia eta minbizi-zelulek erloju honekin dituzten interakzioak aztertzeak ikertzaileen arreta ekarri du [22].

Zenbait ikerketaren arabera, per geneak azpiadierazirik agertzen dira giza minbizi-zeluletan, eta saguetan behatu da per 1 eta per 2 tumore supresore gisa funtzionatzen duten geneak direla [23, 24], besteak beste p53 indukzioa gertatzen ez delako eta zelulek apoptosian sartzeko gaitasun murritzagoa erakusten dute kaltetutako zelulen kopurua emendatuz. Gainera, perl gainadierazten duten giza minbizi-zeluletan hazkuntzaren inhibizioa behatu da [23]. Hala ere, eztabaidan dago erritmo zirkadianoak berak edo bertan parte hartzen duten gene batzuek proliferazio zelularraren gainean eragiten duten. Izatez, erritmo zirkadianoan parte hartzen duten geneetatik 
solik per familiako geneek erakutsi dute tumore supresore ahalmena. Gainera, saguetan ez da korrelazio argirik behatu konportamendu zirkadianoaren galeraren eta tumoreen sorreraren artean [17], baina erritmo zirkadianoa markatzen duten gene batzuen garrantziak gene tumore supresore gisa eta erritmo zirkadianoaren galera minbizia izateko arriskuarekin lotu izanak atzetik egon daitekeen mekanismo molekularraren azalpena bilatzea eragin du.

Zenbait zelulatan, ziklo zelularra ziklo zirkadianoarekin sinkronizaturik dagoela proposatu da. Ziklo zelularra aurrera eramateko beharrezkoak diren zenbait gene (wee 1, G2/M trantsizioan; myc, G0/G1 trantsizioan eta D1 ziklina (ccndl), G1/S trantsizioan) ziklo zirkadianoko zenbait genek erregulatzen dituzte. weel-en adierazpena, esate baterako, CLOCK-BMAL1 konplexuaren oso menpekoa da saguen gibelean [25], eta hepatektomia partziala jaso duten cry -/- saguetan ere weel-en adierazpenean asaldurak behatu dira berriztatze zelularra inhibituz. Dirudienez, weel zelulen zikloaren eta ziklo zirkadianoen arteko gako-lotura bat da. Bere aldetik, $m y c$ genearen adierazpena guztiz blokeatuta azaltzen da per 2 sagu mutanteetan [24], baina enigmatikoki bmall bezalako aktibatzaileek myc-en jarduera erreprimitzen dutela deskribatu da; beraz, dirudienez argitu gabeko transkribapen kontrol bidezidor bat dago [17].

DNA kaltetuta dagoenean ere minbizia sor daiteke, baina zelulek kaltetutako DNA konpontzeko zenbait mekanismo garatu dituzte. DNA-ren konponketa-mekanismo batzuek, Nukleotido-erauzketaren konponketa-mekanismoak adibidez, oszilazio zirkadianoak erakusten ditu bai burmuinean bai eta gibelean ere [26]. Zenbait ikerketek erakutsi dutenez, perl-ek interakzioak ditu DNA kaltetuta dagoenean aktibatzen diren zenbait gako-proteinekin, eta gene honen gainadierazpenak erradiazio ionizantearen pean jarritako minbizi zelulak apoptosian sartzea induzitzen du. Perl-ek, gainera, DNA harizpi bikoitzaren hausturak aktibatzen dituzten mutatutako telangiektasia ataxia (ATM) kinasekin eta CHK2-rekin elkarri eragiten diote [23]. Erritmo zirkadianoan irmotasuna mantentzeko beharrezkoa den beste gene batek, tim-ek (timeless) hain zuzen [27], bestelako proteina gakoekin ere (ataxia telangiektasiarekin eta Rad3-rekin erlazionatuta (ATR) eta CHK1) interakzioak ditu DNA kaltetuta dagoenean, eta dirudienez, tim sentsoreen eta efektoreen arteko bitartekari gisa funtzionatzen du erantzunean [28]. Interakzio hauek soilik egunaren tarte batzuetan gertatzen diren ala ez argi ez dagoen arren, erloju-proteinen adierazpen zirkadianoa horrela izan daitekeela iradokitzen du [17].

Behin baino gehiagotan irakurri dugu (eta irakurriko dugu) Xx. mendean zehar gizarte aurreratuetan sekulako aldaketak izan direla, eta aldaketa horiekin batera, ongizate-mailak inoiz baino altuagoak eskuratu direla. Aldaketa horien guztien artean, argi elektrikoaren erabilpenaren eta distantzia luzeko garraioaren zabalkuntza ez dira txikienak izan. Bidaia 
luzeek eta eguneko momentu ezohikoetan argipean egoteak gure barne erloju zirkadianoa eralda lezake. Gaur egun, obesitatea eta harekin erlazionatutako gaixotasunak (diabetesa, gaixotasun kardiobaskularrak, asma edo minbizia) izateko ohiko arrisku-faktoreei (dieta desorekatuak, bizitza sedentarioa...) erloju zirkadianoaren asaldurak gehitu diezazkiekegu. Gainera zenbait kutsatzailek (kupreak, adibidez) ere erritmo zirkadianoaren galera eragiten dutela proposatu da arrain eta ugaztunetan [29], eta honekin lotuta, azkeneko urteotan hainbeste garatu diren nanoteknologiekin erlazionatutako nanopartikulek (espezifikoki, kupre oxido nanopartikulak) ere erritmo zirkadianoekin erlazionatutako geneetan (cry edo per) alterazioak behatu dira zebra arrainetan [30]. Ikusi dugunez, gorputzaren hainbat prozesu erloju honen menpe daude, eta komeni zaigu erlojua doituta edukitzea.

\section{ESKER ONAK}

Pamela Ruizi bere gomendio eta proposamenek lan hau hobetu besterik ez dutelako egin, eta Vega Asensiori nire zorigaiztoko zirriborroak ganorazko irudietan bilakatu dituelako.

\section{BIBLIOGRAFIA}

[1] DE MAIRAN JJO. 1729. Observation botanique. Histoire de l'Académie Royale des Sciences. 35. Paris.

[2] SOLLBERGER A. 1965. Biological Rhythm Research. Elsevier Publishing Company. $461 \mathrm{pp}$.

[3] KONOPKA RJ., BENZER S. 1971. «Clock mutants of Drosphila melanogaster». Proceedings of the National Academy of Sciences of the United States of America 68, 2112-2116.

[4] HARDIN PE., HALL JC., ROSBASH M. 1990. «Feedback of the Drosophila period gene product on circadian cycling of its messenger RNA levels». Nature 343, 536-540.

[5] ANSARI MW., NADEEM A. 2016. Atlas of Ocular Anatomy. Springer International Publishing. 112 pp.

[6] HATTAR S., LIAO HW., TAKAO M., BERSON DM., YAU KW. 2002. «Melanopsin-Containing Retinal Ganglion Cells: Architecture, Projections, and Intrinsic Photosensitivity». Science 295, 1065-1070.

[7] HANNIBAL J. 2002. «Neurotransmitters of the retino-hypothalamic tract». Cell and Tissue Research. 309, 73-88.

[8] TAKAHASHI JS. 2017. «Transcriptional architecture of the mammalian circadian clock». Nature Reviews Genetics 18, 164-179. 
[9] HIRANO A., FU YH., PLÁCEK LJ. 2016. «The intricate dance of posttranslational modifications in the rhythm of life». Nature Structural \& Molecular Biology 23, 1053-1060.

[10] XU Y., TOH KL., JONES CR., SHIN JY., FU YH., PTÁCEK LJ. 2007. «Modeling of a human circadian mutation yields insights into clock regulation by PER2». Cell 128, 59-70.

[11] XING W., BUSINO L., HINDS TR., MARIONNI ST., SAIFEE NH., BUSH MF., PAGANO M. ZHENG N. 2013. «SCF(FBXL3) ubiquitin ligase targets cryptochromes at their cofactor pocket». Nature 496, 64-68.

[12] ECKEL-MAHAN KL., PATEL VR., MOHNEY RP., VIGNOLA KS., BALDI P SASSONE-CORSI P. 2012. «Coordination of the transcriptome and metabolome by the cricadian clock». Proceedings of the National Academy of Sciences of the United States of America 109, 5541-5546.

[13] FONKEN LK., NELSON RJ. 2014. «The effects of light at night oin circadian clocks and metabolism». Endocrine Reviews 35, 648-670.

[14] BASS J., TAKAHASHI JS. 2010. «Circadian integration of metabolism and energetics». Science 330, 1349-1354.

[15] GNOCCHI D., PEDRELLI M., HURT-CAMEJO E., PARINI P. 2015. «Lipids around the clock: focus on circadian rhythms and lipid metabolism». Biology 4, 104-132.

[16] GLOSSOP NR., HARDIN PE. 2002. «Central and peripheral circadian oscillator mechanism in flies and mammals». Journal of Cell Science 115, 3369-3377.

[17] SAHAR S., SASSONE-CORSI P. 2009. «Metabolism and cancer: the circadian clock connection». Nature Reviews Cancer 9, 886-896.

[18] ABUMRAD NA., DAVIDSON NO. 2012. «Role of the gut in lipid homeostasis». Physiological Reviews 92, 1061-1085.

[19] SHIMBA S., ISHII N., OHTA Y., OHNO T., WATABE Y., HAYASHI M., WADA T., AOYAGI T., TEZUKA M. 2005. «Brain and muscle Arnt-like protein-1 (BMAL1), a component of the molecular clock, regulates adipogenesis». Proceedings of the National Academy of Sciences of the United States of America 102, 12071-12076.

[20] STUCCHI P., GIL-ORTEGA M., MERINO B., GUZMÁN-RUIZ R., CANO V., VALLADOLID-ACEBES I., SOMOZA B., LE GONIDEC S., ARGENTE J., VALET P., CHOWEN J.A., FERNÁNDEZ-ALFONSO M., RUIZ-GAYO M. 2012. «Circadian feeding drive of metabolic activity in adipose tissue and not hyperphagia triggers overweight in mice: is there a role of the pentose-phosphate pathway?». Endocrinology. 153, 690-699.

[21] FONKEN LK., WORKMAN JL., WALTON JC., WEIL ZM., MORRIS JS., HAIM A., NELSON R.J. 2010. «Light and night increases body mass by shifting the time of food intake». Proceedings of the National Academy of Sciences of the United States of America 107, 18664-18669.

[22] GERY S., KOMATSU N., BALDJYAN L., YU A., KOO D., KOEFFLER HP. 2006. «The circadian gene per1 plays an important role in cell growth 
and DNA damage control in human cancer cells». Molecular Cell 22, 375-382.

[23] FU L., PELICANO H., LIU J., HUANG P., LEE C. 2002. «The circadian gene Period2 plays an important role in tumor suppression and DNA damage response in vivo». Cell 111,41-50.

[24] HANSEN J. 2001. «Increased breast cancer risk among women who works predominantly at night». Epidemiology 12, 74-77.

[25] MATSUO T., YAMAGUCHI S., MITSUI S., EMI A., SHIMODA F., OKAMURA H. 2003. "Control mechanism of the circadian clock for timing of cell division in vivo». Science 302, 255-259.

[26] KANG TH., REARDON JT., KENP M., SANCAR A. 2009. «Circadian oscillation of nucleotide escision repair in mammalian brain». Proceedings of the National Academy of Sciences of the United States of America 106, 2864-2897.

[27] BARNES JW., TISCHKAU SA., BARNES JA., MITCHELL JW., BURGOON PW., HICKOK JR., GILLETTE MU. 2003. «Requirement of mammalian timeless for circadian rhythmicity». Science 302, 439-442.

[28] UNSAL-KAÇMAZ K., MULLEN TE., KAUFMANN WK., SANCAR, A. 2005. «Coupling of human circadian and cell cylces by timeless protein». Molecular Cell Biology 25, 3109-3116.

[29] HANDY RD. 2003. "Chronic effects of copper exposure versus endocrine toxicity: two sides of the same toxicological process?». Comparative Biochemistry and Physiology A. 135, 25-38.

[30] VICARIO-PARES U., LACAVE JM., REIP P., CAJARAVILLE MP., ORBEA A. 2018. «Cellular and molecular responses of adult zebrafish after exposure to $\mathrm{CuO}$ nanoparticles or ionic copper». Ecotoxicology 27 89-101. 